\title{
Ly49 receptors: innate and adaptive immune paradigms
}

\author{
Mir Munir A. Rahim ${ }^{1}$, Megan M. Tu ${ }^{1}$, Ahmad Bakur Mahmoud ${ }^{1,2}$, Andrew Wight ${ }^{1}$, Elias Abou-Samra ${ }^{1}$, \\ Patricia D. A. Lima ${ }^{3}$ and Andrew P. Makrigiannis ${ }^{1}$
}

1 Department of Biochemistry, Microbiology and Immunology, University of Ottawa, Ottawa, ON, Canada

${ }^{2}$ College of Applied Medical Sciences, Taibah University, Madinah Munawwarah, Kingdom of Saudi Arabia

${ }^{3}$ Biomedical and Molecular Sciences, Queen's University, Kingston, ON, Canada

\section{Edited by:}

Linde Meyaard, University Medical

Center Utrecht, Netherlands

Reviewed by:

Janos G. Filep, University of

Montreal, Canada

T. Sakari Jokiranta, University of

Helsinki, Finland

*Correspondence:

Mir Munir A. Rahim, Department of Biochemistry, Microbiology and

Immunology, University of Ottawa,

Roger Guindon Hall, Room 4226, 45

Smyth Road, Ottawa, ON K1H 8M5,

Canada

e-mail:mrahim@uottawa.ca
The Ly49 receptors are type II C-type lectin-like membrane glycoproteins encoded by a family of highly polymorphic and polygenic genes within the mouse natural killer (NK) gene complex. This gene family is designated KIra, and includes genes that encode both inhibitory and activating Ly49 receptors in mice. Ly49 receptors recognize class I major histocompatibility complex-I (MHC-I) and MHC-I-like proteins on normal as well as altered cells. Their functional homologs in humans are the killer cell immunoglobulin-like receptors, which recognize HLA class I molecules as ligands. Classically, Ly49 receptors are described as being expressed on both the developing and mature NK cells. The inhibitory Ly49 receptors are involved in NK cell education, a process in which NK cells acquire function and tolerance toward cells that express "self-MHC-I." On the other hand, the activating Ly49 receptors recognize altered cells expressing activating ligands. New evidence shows a broader Ly49 expression pattern on both innate and adaptive immune cells. Ly49 receptors have been described on multiple NK cell subsets, such as uterine NK and memory NK cells, as well as NKT cells, dendritic cells, plasmacytoid dendritic cells, macrophages, neutrophils, and cells of the adaptive immune system, such as activated T cells and regulatory $\mathrm{CD} 8^{+} \mathrm{T}$ cells. In this review, we discuss the expression pattern and proposed functions of Ly49 receptors on various immune cells and their contribution to immunity.

Keywords: Ly49, innate immune receptors, NK cells, innate immunity, receptor function

\section{INTRODUCTION}

Major histocompatibility complex (MHC) recognition is central to both innate and adaptive immune recognition. The function of both the innate immune effectors, such as natural killer (NK) cells, and the adaptive immune effectors, such as $\mathrm{T}$ cells, depend upon the recognition of MHC-I molecules expressed on aberrant cells; however, the mode of recognition varies between the two lymphocyte subsets. T cell receptors (TCR) have specificity to the antigenic peptide bound to MHC-I and form contacts to the peptide as well as to the MHC molecule $(1,2)$. NK cell receptors, such as the Ly49 in mice, bind MHC-I molecules in a peptidedependent but not peptide-specific manner (3). An exception is the Ly49C, a member of the Ly49 receptor family (Table 1), whose binding to $\mathrm{H}-2 \mathrm{~K}^{\mathrm{b}}$ haplotype appears to be peptide-specific $(3,4)$. The binding interface between Ly49 and MHC-I, revealed from crystal structures of Ly $49 \mathrm{~A}$ and $\mathrm{H}-2 \mathrm{D}^{\mathrm{b}}$ molecules, is distinct and away from the peptide binding groove on MHC-I (5). While signals downstream of TCR engagement specifically activate T cell functions, the Ly49 receptors can be activating or inhibitory in nature, and their expression is not limited to NK cells. In addition to NK cells, other leukocytes have also been shown to express inhibitory Ly49 receptors, such as the $\mathrm{CD}^{+}{ }^{+} \mathrm{T}$ cells, $\mathrm{CD}^{+}$cells, intestinal epithelial lymphocytes (IELs), NKT cells, uterine NK cells (uNK) cells, and cells of the myeloid lineage (6-12). Here, we review the expression of Ly49 receptors on different cells of the innate and adaptive immune system (Figure 1), and their contribution to immunity.

\section{Ly49 RECEPTORS}

The innate MHC-I receptors include the human killer cell immunoglobulin-like receptor (KIR), NKG2/CD94, and mouse Ly49 families of receptors. The genes that encode the mouse MHCI receptors are clustered together in the natural killer gene complex (NKC) on mouse chromosome 6. The Ly49 receptors are homodimeric type II glycoproteins of the C-type lectin-like superfamily. They are structurally distinct but functionally similar to human KIR in terms of MHC-I recognition, and therefore provide a useful model system to study the role of this class of receptors in immune regulation. A list of activating and inhibitory Ly49 receptors in different mouse strains and KIR in humans is shown in Table 1. MHC-I receptors generally inhibit NK cell function when they are engaged by self-MHC ligands. Therefore, inhibitory Ly 49 receptors are generally agreed to be important for the prevention of autoimmunity by suppressing NK cell activation. The acquisition of inhibitory Ly49 for self-MHC-I is also a key step in the "licensing" of developing NK cells to avoid a hyporesponsive state (Figure 2A) (13). In contrast, the activating Ly49 receptors recognize ligands that are expressed on abnormal or infected cells, and activate cytokine production and cellular cytotoxicity by NK cells. The integration of signals from the activating and inhibitory Ly 49 receptors ultimately determines the functionality of NK cells.

\section{INTRACELLULAR SIGNALING}

The inhibitory and activating members of Ly 49 and KIR families are characterized by the presence or absence of immunoreceptor 
tyrosine-based inhibitory motif (ITIM) domains in their cytoplasmic tail (14-16). NK cell stimulation results in differential phosphorylation of Ly49 receptors. Mason and co-workers first reported that tyrosine phosphorylation was restricted to the inhibitory Ly49 molecules such as Ly49 A, C/I, and G2, while the activating Ly49D was not phosphorylated (17). The

Table 1 | Mouse Ly49 and human KIR receptors for MHC-I.

\begin{tabular}{|c|c|c|c|c|c|}
\hline \multicolumn{4}{|c|}{ Mouse $^{a}$} & \multirow[t]{2}{*}{ Human } & \multirow[t]{2}{*}{ Function } \\
\hline NOD & 129 & B6 & BALB & & \\
\hline Ly49D & Ly49P & Ly49D & Ly49L & KIR2DL4 & Activating \\
\hline Ly49H & Ly49R & Ly49H & & KIR2DS1 & \\
\hline Ly49M & Ly49U & & & KIR2DS2 & \\
\hline Ly$_{49 P_{1}}$ & & & & KIR2DS3 & \\
\hline $\mathrm{Ly}_{49 P_{3}}$ & & & & KIR2DS4 & \\
\hline Ly49U & & & & KIR2DS5 & \\
\hline Ly49W & & & & KIR3DS1 & \\
\hline Ly49A & Ly49B b & Ly49A & Ly49A & KIR2DL1 & Inhibitory \\
\hline${\text { Ly } 49 B^{b}}^{b}$ & Ly49E & Ly49B b & Ly49B $^{b}$ & KIR2DL2 & \\
\hline Ly49C & Ly$_{49} \mathrm{EC}_{2}$ & Ly49C & Ly49C & KIR2DL3 & \\
\hline Ly49E & Ly49G & Ly49E & Ly49E & KIR2DL5 & \\
\hline Ly49F & Ly49| & Ly49F & Ly49G & KIR3DL1 & \\
\hline $\mathrm{Ly}_{49} \mathrm{G}_{2}$ & Ly490 & Ly49G & Ly49| & KIR3DL2 & \\
\hline Ly49| & Ly490 1 & Ly49| & Ly490 & & \\
\hline \multirow[t]{3}{*}{ Ly490 } & Ly49S & Ly49J & & & \\
\hline & Ly49T & Ly490 & & & \\
\hline & Ly49V & & & & \\
\hline
\end{tabular}

${ }^{a}$ Ly49 pseudogenes do not encode any functional product and are not included. ${ }^{b}$ Encoded by a gene outside the Ly 49 gene cluster. phosphorylated Ly49 molecules were shown to be associated with the src homology 2 ( $\mathrm{SH} 2$ ) domain-containing protein phosphatase SHP-1 in this study (17). Phosphorylation of the tyrosine residue within the ITIM is responsible for the recruitment and activation of SH2 domain-containing protein tyrosine phosphatases (18). Although SHP-1 appears to be the major phosphatase required for Ly49-mediated inhibition, it may not be the only inhibitory mediator since Ly49A function is diminished but not completely absent in mice deficient in SHP-1 (19). Although engagement of inhibitory receptors results in ITIM phosphorylation, it is greatly enhanced when it is cross-linked to an activating receptor complex $(20,21)$. This demonstrates an elegant regulatory mechanism whereby inhibitory receptor phosphorylation induced by engagement of activating receptors results in recruitment of protein tyrosine phosphatases, and the subsequent suppression of tyrosine phosphorylation-based signals downstream of the activating receptors. In contrast to the inhibitory receptors, the activating Ly49 receptors transduce signals through associated adaptor proteins, such as DAP12, which possess an immunoreceptor tyrosine-based activation motif (ITAM) (22-24). This interaction is mediated by a charged residue (arginine) in the transmembrane segment of Ly49, as was shown for Ly49D (25). Cross-linking of activating Ly49 leads to phosphorylation of tyrosine residues within the ITAM of DAP12 as well as phosphorylation of other proteins, including members of the Src-family of tyrosine kinases, the mediators of downstream signaling events (26).

\section{GENETIC DIVERSITY}

One of the striking features of Ly49 receptors is the polymorphic and polygenic nature of the $L y 49$ gene cluster among the inbred mouse strains (27-30). This results in heterogeneity in both the type and level of Ly49 molecules expressed in different mouse strains (Table 1) (31). Among the four inbred mouse strains whose Ly49 gene haplotypes have been extensively characterized, the



FIGURE 1 | Schematic representation of cell types expressing Ly49 receptors. Receptor repertoire and proposed functions of Ly49 in different cellular subsets is shown based on literature reports in C57BL/6 mice. NK, natural killer; uNK, uterine natural killer; NKT, natural killer T; DC, dendritic cells; pDC, plasmacytoid dendritic cell; $\alpha$-GalCer, $\alpha$-galactosylceramide; VEGF-A, vascular endothelial growth factor $A ;$ TLR, Toll-like receptor; IFN-I, type I interferon; n.d., not determined. 


\section{A Education and licensing of developing NK cells}
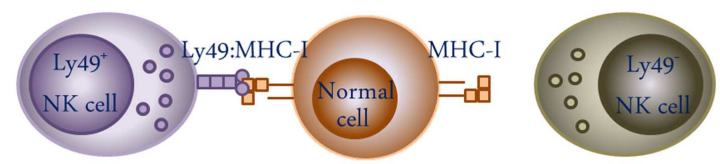

Educated/Licensed

Uneducated/Unlicensed

\section{B Immunosurveillance (missing-self recognition)}
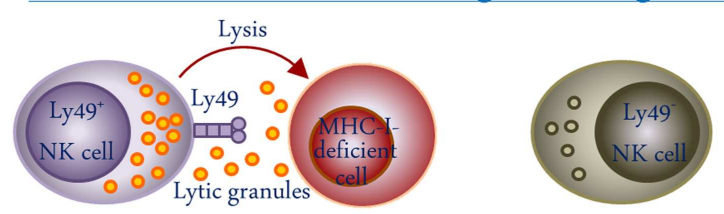

Educated/Licensed

Uneducated/Unlicensed

\section{c Immunosurveillance of MHC-I-sufficient tumors}

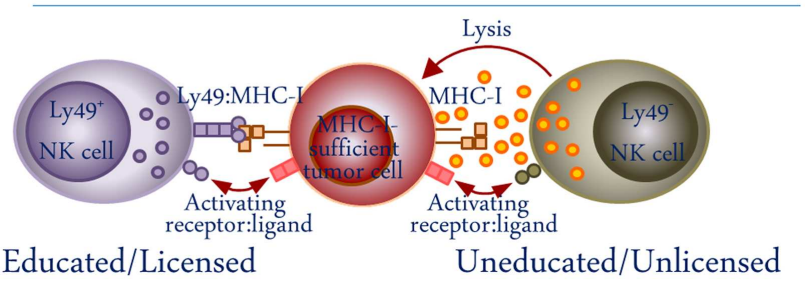

FIGURE 2 | Schematic representation of the role of Ly49 receptors in NK cell development and function. (A) During NK cell development, interactions between the inhibitory Ly 49 receptors and their self-MHC-I ligands on normal cells result in NK cell functional maturation (education/licensing). (B) Licensed Ly49+ but not unlicensed Ly49- NK cells recognize $\mathrm{MHC}$-I-deficient cells and kill them through the release of lytic granules (missing-self recognition). (C) Tumor cells express ligands which are recognized by activating receptors on NK cells. However, MHC-l-expressing tumor cells can inhibit licensed NK cells through interactions with their inhibitory Ly49 receptors. Unlicensed NK cells will not be inhibited in this way because they lack Ly49 receptors.

BALB/c mouse strain possess the smallest haplotype with 8 genes (32), and the NOD/ShiLtJ strain possess the largest haplotype with 21 discernable genes (33). The C57BL/6 haplotype, which was the first to be characterized, and the 129 mouse strain haplotype possess 15 and 19 genes, respectively $(28,29,34-36)$. In all the characterized $L y 49$ haplotypes, there appears to be a limited degree of conservation in the form of "framework" genes which delineate the regions of variable numbers of strain-specific genes. The framework gene pairs in mice are $L y 49 q-e, L y 49 i-g$, and $L y 49 c-a$. Ly 49 haplotype diversity has evolved as a result of multiple duplication and deletion events. Examples of strain-specific Ly49 gene inactivation are evident in different strain of mice mostly mediated by stop codons within the coding region (37-39). Such diversity is possibly driven by selective pressure due to pathogenic challenge, since NK cells appear to be critical for the control of viral infections $(40,41)$. In mice, the activating $\mathrm{Ly} 49 \mathrm{H}$ receptor directly interacts with the murine cytomegalovirus (MCMV) 157 gene product on NK cells and confers resistance to MCMV in the C57BL/6 mouse

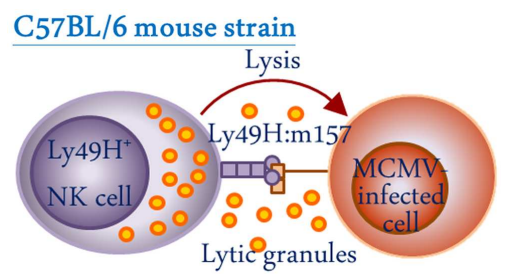

129 and $\mathrm{BALB} / \mathrm{c}$ mouse strains



FIGURE 3 | Schematic representation of the role of the activating Ly49H receptors in recognition of MCMV-infected cells. NK cells from C57BL/6 but not 129 or BALB/C mouse strains express Ly $49 \mathrm{H}$ and are capable of recognizing $\mathrm{m} 157$ viral protein on the surface of MCMV-infected cells, thereby, conferring resistance against MCMV infection.

strain which possesses the $L y 49 h$ gene (Figure 3). Conversely, 129 and BALB/c strains lack the gene for activating $\mathrm{Ly} 49 \mathrm{H}$ and hence are highly susceptible to MCMV infection (42-47).

\section{Ly49 EXPRESSION AND FUNCTION ON NK CELLS}

Ly49 receptors are best known for their role in the regulation of NK cell functions. Both the activating and inhibitory Ly49 receptors are expressed by NK cells (Figure 1). Murine NK cells express up to six members of the Ly49 receptor family in an overlapping fashion, such that the average NK cell expresses two to three Ly49 receptors (48). Ly49 expression begins early during NK cell development in the bone marrow (BM). An in vivo differentiation study demonstrated that there are five stages of NK cell development in murine $\mathrm{BM}$, as assessed by surface expression of NK cell markers (49). In the first three stages of development, NK cells sequentially attain expression of CD122 (stage I; CD122+ ${ }^{+} \mathrm{NK} 1.1^{-} \mathrm{DX}^{-} \mathrm{Ly}^{-} 9^{-}$), then NK1.1, DX5, and NKG2A (stage II; CD122 ${ }^{+} \mathrm{NK} 1.1^{+} \mathrm{DX}^{\text {lo }}$ CD94/NKG2A ${ }^{+}$Ly49 $^{-}$), and finally Ly49 at stage III. Afterward, immature NK cells undergo extensive cell division and expansion in stage IV followed by functional maturation at stage $\mathrm{V}$ of their development (49). Ly49E is the only member of Ly49 family that is expressed on fetal NK cells and its expression is lost early after birth (50). Expression of other Ly49 family members are detected on developing NK cells during the first 2-3 weeks after birth and reach optimal levels within $6-8$ weeks after birth $(50,51)$.

\section{NK CELL EDUCATION AND TARGET CELL RECOGNITION}

Ly49 receptors play an important role in NK cell education and recognition of target cells. The mechanism behind NK cell recognition of target cells was discovered by Kärre and colleagues, and accordingly named the "missing-self hypothesis" (Figure 2B) (52). According to the hypothesis, NK cells survey MHC-I expression on cells with which they come into contact (52). Abnormal or infected cells often down-regulate expression of MHC-I on their surface in order to avoid detection and killing by cytotoxic T cells; however, 
this down-regulation is recognized by, and functions as a kill signal for NK cells (52). In this seminal work, the RBL-5 lymphoma cell line was mutagenized to derive two new cell lineages, an MHCI-expressing RMA and MHC-I-deficient RMA-S. It was observed that the MHC-I-deficient RMA-S cells, following injection into mice, were rapidly eliminated while the MHC-I-expressing RMA cells were able to develop into tumors (52). This "missing-self" hypothesis was further supported by the finding that cells isolated from mice lacking expression of $\beta_{2} \mathrm{~m}$, the light chain component of MHC-I that is necessary for its surface expression, were readily recognized and killed by $\mathrm{NK}$ cells, while re-introduction of a $\beta_{2} \mathrm{~m}$ transgene restored the resistance to NK cell killing (53). In addition to the increased susceptibility of cells isolated from MHC-I-deficient mice to NK cell killing, it was also noted that NK cells from $\beta_{2} \mathrm{~m}^{-1-}$ mice exhibited a diminished ability to kill traditional NK cell targets, when compared to wild-type (WT) mice (53). This led to the proposal that MHC-I interactions during NK cell development are needed for induction of NK cytolytic activity (Figure 2A). This hypothesis was later substantiated by the discovery that NK cells must undergo an MHC-I-dependent "licensing" process in order to be functional, in which a selfspecific Ly49 receptor interacts with self-MHC-I (13). Similarly, we have demonstrated that the NK cells from Ly49-deficient mice are unlicensed and show impaired missing-self response against MHC-I-deficient target cells (54). This education requirement has also been found in human NK cells with the interaction of MHCI and $\operatorname{KIR}(55,56)$. The licensed NK cells are functionally active while at the same time self-tolerant due to recognition of MHC-I through their inhibitory Ly49 receptors. In contrast, the unlicensed NK cells - which lack self-MHC-specific inhibitory receptors - are tolerant due to their hyporesponsive nature.

The mechanics of the education process are still unknown, with various contested models. While education was originally thought to occur during NK cell development in the BM (13), adoptive transfer studies utilizing splenic NK cells from MHC-I deficient mice into WT hosts were able to restore NK functionality, thus showing that education does not occur only during development of immature NK cells, but is actually a dynamic and reversible process $(57,58)$. The arming and disarming model are the most widely accepted models thus far. Based on the arming model, NK cells which lack expression of an inhibitory self-MHCI-specific Ly49 receptor are unable to fully mature into functional NK cells (become "armed") and thus remain in their hyporesponsive state (59). In contrast, the disarming model proposes that NK cells which lack expression of an inhibitory self-MHC-I-specific Ly49 receptor, and thus are chronically stimulated due to lack of inhibitory signaling, become anergic and hyporesponsive to target cells (59).

The type of interaction between the Ly49 receptor and the MHC-I molecule during education has also been shown to be important and somewhat controversial: it is unknown whether the Ly49 is interacting in cis with MHC-I on the NK cell surface itself or in trans with the MHC-I expressed on another cell. Transmediated licensing is supported by various groups, using either adoptive transfer from MHC-I-deficient mice in WT recipients or doxycycline-inducible MHC-I expression in MHC-I-deficient $\beta_{2} \mathrm{~m}^{-/-}$mice to observe interactions between MHC-I-deficient
NK cells in an MHC-I-sufficient environment (57, 58, 60). On the other hand, using a modified Ly49A receptor, which is only capable of binding in trans with ligands on other cell surfaces but not in cis, Chalifour and colleagues found that NK cells from these mice did not appear to be fully educated (61). As well, Bessoles and colleagues' recent work also suggests a cis interaction contribution to NK functionality, though the precise role is not clear (62).

\section{NK CELL-MEDIATED IMMUNOSURVEILLANCE}

Major histocompatibility complex-I-dependent "missing-self" recognition by NK cells has great implications on the immunosurveillance of abnormal cells which have lost surface expression of MHC-I molecules. Lost or aberrant surface expression of MHCI in human tumors is classified into seven phenotypes as follows: (1) total HLA loss, (2) HLA haplotype loss, (3) HLA locus loss, (4) HLA allelic loss, (5) compound phenotypes, (6) unresponsiveness to interferons (IFNs), and (7) gain of MHC-Ib (63). Altered MHCI expression is highly prevalent in human tumors and various alterations have been associated with different cancer types: HLA haplotype loss is the most common alteration and has been described in laryngeal (64), non-Hodgkin's lymphoma (65), and pancreatic cancer (66). Loss of MHC-I expression along with up-regulation of ligands for activating NK cell receptors on tumor cells results in their recognition and elimination by NK cells. We have shown that Ly49-deficient mice are unable to recognize and eliminate MHCI-deficient target cells (54). On the other hand, the 5E6 antibody (to block the inhibitory Ly49I/C signaling) and 1-7F9 antibody (to block KIR signaling) have been shown to be useful in the treatment of leukemia and multiple myeloma in mice and humans, respectively; therefore, manipulation of human KIR signaling has been proposed as a potential cancer therapeutic (67-70). Finally, there is also evidence that a member of the Ly49 receptor family, Ly49A, recognizes the non-classical MHC-I molecule $\mathrm{H} 2-\mathrm{M} 3$ and in part mediates NK cell licensing (71). Ly49A ${ }^{+}$NK cells from WT mice exhibit enhanced responsiveness compared to $\mathrm{H} 2-\mathrm{M} 3$-deficient mice. H2-M3-deficient mice display defective tumor control with increased B16F10 pulmonary metastatic burden, and increased incidence of MCA-induced fibrosarcoma $(71,72)$.

More recently, a paradigm shift was suggested following the study by Tarek and colleagues, wherein it was found that unlicensed NK cells are better at killing neuroblastoma tumors (73). Unlike the traditionally low levels of MHC-I expression on tumors, neuroblastoma cells express high levels of MHC-I, which can inhibit licensed NK cells. On the other hand, the unlicensed NK cells are not inhibited by MHC-I on neuroblastoma cells (Figure 2C). It was found that patients lacking HLA ligands for their KIRs showed improved prognosis and survival when treated with $3 \mathrm{~F} 8$, an antibody targeting the disialoganglioside surface antigen, in contrast to the educated NK cells which were selectively inhibited by HLA ligands expressed on the tumor cells (73). In such case, the inhibitory signals through KIR-dependent recognition of HLA on the target cell dampen the beneficial effect of educated NK cells. Blocking this KIR interaction with MHC-I could prove therapeutically beneficial in such circumstances.

The Ly49 receptors on NK cells also play a role in immunity against virus infections. The importance of NK cells in innate defense against viral infections was highlighted by studies which 
have shown severe and recurrent infections by otherwise benign viruses in individuals lacking NK cell functions (40,41). Viruses have developed several strategies to evade recognition of NK cells. This may occur by expression of viral proteins on infected cells that resemble host MHC-I molecules and inhibit NK cells through interaction with the inhibitory receptors, or by down-regulation of activating ligands on the surface of infected cells (74). The arms race between the viruses and NK cells has resulted in the selection of receptors for their ability to specifically recognize virus-infected cells. For instance, the activating $\mathrm{Ly} 49 \mathrm{H}$ receptor on NK cells has evolved to recognize the glycoprotein $\mathrm{m} 157$, a MCMV-encoded structural homolog of MHC-I, on the surface of infected cells and imparts resistance in the C57BL/6 mouse strain (Figure 3) (46). Ly49H-deficient C57BL/6 mice and other mouse strains (129 and BALB/c), which lack the gene encoding for Ly49H, are highly susceptible to MCMV infection (43, 46, 47). The mutant MCMV strain that lacks m157 glycoprotein is significantly more virulent in C57BL/6 mice (75), indicating an important role for Ly49H in host defense against MCMV. Similarly, the activating Ly49P receptor protects MA/My mice from lethal MCMV infection through the recognition of MCMV-encoded $\mathrm{m} 04$ proteins in association with $\mathrm{H}-2 \mathrm{D}^{\mathrm{k}}$ MHC-I haplotype (76). Mutant MCMV strains that lack m04 are lethal in MA/My mice since this mouse also lacks the activating $\mathrm{Ly} 49 \mathrm{H}$ (77). Interestingly, Orr and colleagues have demonstrated that $\mathrm{Ly}_{49 \mathrm{H}^{+}} \mathrm{NK}$ cells that do not express inhibitory Ly49 receptors are more efficient in controlling MCMV infection than $\mathrm{Ly}_{4} 9 \mathrm{H}^{+} \mathrm{NK}$ cells that express inhibitory Ly49 receptors, possibly due to the lack of inhibitory signals in the former (78). Therefore, blocking inhibitory receptors on NK cells may have beneficial therapeutic effects in certain viral infections, as has been shown in cancers of humans and mice (67-70).

\section{Ly49 EXPRESSION AND FUNCTION ON UTERINE NK CELLS}

Uterine NK cells ( $\mathrm{uNK}$ ) are resident lymphocytes of the uterus. In the non-pregnant mouse uterus, uNK cells are few and express CD122, CD49b (DX5), NKp46, CD11b, CD27, and CD69; a phenotype similar to peripheral blood and spleen NK cells $(11,79)$. These cells also express Ly49G2 $(80,81)$. During pregnancy, a massive influx of NK cells expressing Ly49 receptors occurs in the mouse decidualized uterus $(11,82-84)$. In the decidua, two subsets of uNK cells are identified based on the expression of $N$-acetylD-galactosamine, which can bind the Dolichos biflorus agglutinin (DBA) lectin: $\mathrm{DBA}^{+}$and $\mathrm{DBA}^{-}$subsets $(11,83)$. Both subsets are known to express Ly49 receptors (Figure 1) (11). $\mathrm{DBA}^{-} \mathrm{uNK}$ cells originate from NK progenitors cells ( $\mathrm{Lin}^{-} \mathrm{CD} 122^{+} \mathrm{NK} 1.1^{-}$) and like splenic NK cells, they are the source of decidual IFN- $\gamma$. However, their frequency remains constant throughout the pregnancy $(11,84,85) . \mathrm{DBA}^{+} \mathrm{uNK}$ cells are absent in the non-pregnant uterus, expand dramatically up to mid-gestation (gestational day 8.5-10.5), and decrease again in late pregnancy $(11,83,86)$. The $\mathrm{DBA}^{+} \mathrm{uNK}$ cells have a unique receptor repertoire which includes Ly49 receptors (11). Early in pregnancy, they perform potent vasculo-angiogenic activity demonstrating that they are active $\mathrm{NK}$ cells (85-90). The origin of $\mathrm{DBA}^{+} \mathrm{uNK}$ cells is unclear, but uterus transplant experiments suggest that $\mathrm{DBA}^{+} \mathrm{uNK}$ cells are recruited from the circulation (91).
The Ly49 receptor repertoires of $\mathrm{DBA}^{+}$and $\mathrm{DBA}^{-}$uNK cells differ. Ly49C/I and D are expressed at low levels and Ly49G2 is highly expressed on $\mathrm{DBA}^{+}$compared to the $\mathrm{DBA}^{-}$uNK cells, while Ly49A and $H$ are expressed at similar levels (11). They seem to play an important role during mouse pregnancy. Antigenic disparity between parental $\mathrm{H}-2 \mathrm{~K}$ genes (BALB/C: $d$ haplotype and B6: b haplotype) affects the trophoblast-induced transformation of uterine vasculature (92). In the B6 mouse strain, the trophoblast giant cells express high levels of $\mathrm{H}-2 \mathrm{~K}^{\mathrm{b}}$ and $\mathrm{H}-2 \mathrm{D}^{\mathrm{b}}$, the ligands for various Ly49 receptors (92-94). Our observation of pregnancy defects in the Ly49-knockdown mouse model and the works described above, suggest an important role of Ly49 receptors on uNK cells in mouse pregnancy.

In addition to their role in normal pregnancy, uNK cells can act as effector cells against infectious agents at the maternal-fetal interface. Human cytomegalovirus (HCMV) is the most common cause of intra-uterine and congenital virus infection (95). Human uNK cells have been shown to display cytotoxic effector function upon recognition of HCMV-infected cells (96). During mouse pregnancy, MCMV infection results in vascular dysfunction of mesenteric and uterine arteries (97). The activating $\mathrm{Ly} 49 \mathrm{H}$ receptor is responsible for recognition and elimination of MCMV-infected cells (46). In addition, uNK cells express several vaso-active factors to regulate vaso-constriction and dilation (98), thereby making them potential modulators during normal and infectious pregnancy complications.

\section{Ly49 EXPRESSION AND FUNCTION ON NKT CELLS}

NKT cells are defined as CD1d-restricted T cells that express an invariant $\mathrm{T}$ cell antigen receptor, variable $(\mathrm{V})$ and joining $(\mathrm{J})$ $\mathrm{V} \alpha 14 \mathrm{~J} \alpha 18$ in mice, and $\mathrm{V} \alpha 24 \mathrm{~J} \alpha 18$ in humans, combined with a limited TCR $\beta$ chain repertoire (V $\beta 8.2, \mathrm{~V} \beta 7$, or $\mathrm{V} \beta 2$ in mice and $\mathrm{V} \beta 11$ in humans). These TCR $\alpha \beta$-chain combinations result in NKT cells with specificity for glycolipid antigens presented by the MHC-I-related CD1d surface protein $(99,100)$.

Murine TCR $\alpha \beta^{+} \mathrm{NK} 1.1^{+}$NKT cells are known to express other NK cell-associated molecules including CD122, CD16, DX5, CD94/NKG2, and the Ly49 family of receptors. Thus far, only inhibitory Ly49 receptors have been shown to be expressed on NKT cells (Figure 1) (101). One reason for this could be that, forced expression of Ly49D, an activating receptor, on $\mathrm{T}$ cells by transgenesis results in impaired thymocyte maturation (102). It has been shown that Ly49 expression inversely correlates with their response to $\alpha$-galactosylceramide ( $\alpha$-GalCer), a potent stimulator of CD1d-restricted NKT cells. MHC-I-dependent $\alpha$-GalCer presentation by dendritic cells (DC) stimulates Ly49- but not Ly49 ${ }^{+}$NKT cells (12). On the other hand, MHC-I-deficient DCs effectively present $\alpha$-GalCer to Ly49 ${ }^{+}$splenic NKT cells. When Ly49:MHC-I interactions are blocked using anti-Ly49 A, C/I, and $\mathrm{G}$ monoclonal antibodies (mAb), Ly49 ${ }^{+}$NKT cells were efficiently stimulated with $\alpha$-GalCer-pulsed DCs, demonstrating inhibition of TCR-mediated activation signals by inhibitory Ly49:MHC-I interactions on NKT cells (101). Therefore, Ly49 receptors appear to have a similar role in regulating NKT cell responses as has been described for NK cells.

Expression of Ly 49 and response to $\alpha$-GalCer vary greatly among NKT cells from different anatomical sites. Almost 85\% 
of splenic CD1d-independent NKT cells from $\beta 2 \mathrm{~m}$-deficient mice express Ly49A, C, G, or I, whereas only $50 \%$ of splenic NKT cells from WT mice express these Ly49 receptors (12). In the mouse thymus, over $75 \%$ of NKT cells stain with CD1d tetramers (103). Similarly, Oberg and colleagues have reported that almost 70\% of thymic NKT cells express Ly49A, C, G, or I (12). Despite the high percentage of CD1d-restricted NKT cells in the thymus, thymic NKT cells are weakly stimulated with $\alpha$-GalCer-pulsed DCs as compared with splenic NKT cells. The inability of most thymic NKT cells to respond to $\alpha$-GalCer does not seem to be due to inhibition via Ly49:MHC-I interaction, because $\alpha$-GalCerpulsed MHC-I-deficient DCs also fail to stimulate thymic NKT cells (104). It seems likely that CD1d-restricted Ly49 ${ }^{+}$thymic NKT cells may be functionally immature and may constitute the precursors for mature CD1d-restricted NKT cells. Whereas thymic NKT cells are thought to be precursors of splenic CD1drestricted NKT cells, the origin of NKT cells in BM is still unclear. Phenotypically, they are different from thymic NKT cells (105), and are thought to be extra-thymically derived (106). Almost $85 \%$ of BM NKT cells express Ly49A, C, G, or I, however, only $30 \%$ of them bind CD1d tetramers (103). Like their thymic counterparts, BM NKT cells do not respond to $\alpha$-GalCer-pulsed MHC-I-sufficient and-deficient DCs. It remains to be determined whether all CD1d-restricted BM NKT cells are Ly49 ${ }^{+}$, and whether they are immature NKT cells belonging to a separate NKT cell lineage.

\section{Ly49 EXPRESSION AND FUNCTION ON CELLS OF THE MYELOID LINEAGE}

While most members of Ly49 family of receptors are exclusively expressed on NK, NKT, and T cell subsets, Ly49Q and B have a unique pattern of expression and are found on distinct subsets of myeloid lineage cells $(6,8,107)$. Ly49B is expressed on multiple distinct subpopulations of myeloid cells defined by CD11b and Gr-1 expression, with morphological characteristics of granulocytes and monocyte/macrophages (8). Ly49B expression was generally low in these cells and was up-regulated when cells were treated with lipopolysaccharide (LPS), IFN- $\alpha$, and IFN- $\gamma$. Cells expressing Ly49B were reported to be more numerous in the Peyer's patches and the lamina propria of the gut, implicating a role of Ly49B in gut immunobiology (8). Interestingly, Ly49B and $\mathrm{Q}$ were reported to be expressed on non-overlapping myeloid subpopulations among freshly isolated spleen and BM cells (8). Ly49Q is an inhibitory receptor and has been shown to associate with SHP-1/2 upon cross-linking (107). Its expression was detected on $\mathrm{Gr}-1^{+}$cells in mouse fetal liver and adult BM and spleen. Expression was found to be higher on immature myeloid precursors and IFN- $\gamma$-treated macrophages (107). Ly49Q crosslinking on macrophage cell lines induces formation of cell polarity and spreading through cell cytoskeletal rearrangement (Figure 1) (107). Similarly, Ly49Q appears to be essential for cellular polarization and invasion of extravascular tissues by neutrophils during an inflammatory response (Figure 1) (108). In addition, Ly49Q expression is induced on osteoclasts which differentiate from the monocyte/macrophage lineage cells by receptor activator of nuclear factor- $\mathrm{B}$ ligand (RANKL) treatment, and plays a role in osteoclastogenesis (109).
Another myeloid lineage cell type that expresses high levels of Ly49Q is the plasmacytoid dendritic cell (pDC) (Figure 1). Virtually all peripheral and the majority of BM pDCs express Ly49Q, which also correlates with the sequential development and activation of these cells $(6,7,110)$. pDCs are specialized in direct virus recognition and secretion of large amounts of IFN-I early during infection $(111,112)$. Using a gene knockout mouse model, we have shown that Ly49Q, despite being an inhibitory receptor, positively regulates Toll-like receptor (TLR)mediated IFN-I production by pDCs $(113,114)$. In mice lacking Ly49Q, both TLR7 and TLR9-mediated IFN-I production by pDCs is attenuated (113). Although the precise mechanism of this positive regulation is not known, it is Ly49Q ITIMdependent but may not involve interaction with the SHP-1/2 phosphatases (114). One of the possible mechanisms could be a cooperative activation of interferon regulatory factors (IRF) in conjunction with TLR-mediated downstream signals, leading to enhanced IFN-I production. Alternatively, Ly49Q may aid in the uptake of microbial macromolecules, such as unmethylated $\mathrm{CpG}$ oligodeoxynucleotides (ODN), and their trafficking to endosomal compartments where TLRs are located. We have demonstrated a specific down-regulation of Ly49Q from the pDC surface when treated with TLR9 agonist CpG ODN (114). This is similar to the down-regulation and co-internalization of human KIR3DL2 with CpG ODN in NK cells (115). A direct in vitro binding of CpG ODN to KIR3DL2 was also shown in this study. Co-localization of Ly49Q with CpG ODN in TLR9 containing endosome/lysosome compartments has previously been demonstrated, however it remains to be determined if Ly49Q is the sensor and distributor of CpG ODN to these compartments (116).

\section{Ly49 EXPRESSION AND FUNCTION ON CD8+ T CELL SUBSETS} Although Ly49 receptors are best known as innate immune receptors, their expression is not limited to the cells of the innate immune system which we have discussed above (Figure 1). Here, we will shift our attention to the Ly49-expressing T cells from the CD8 lineage, cells of the adaptive immune system. This population, along with the analogous KIR-expressing $\mathrm{CD} 8^{+} \mathrm{T}$ cells in humans, has only recently garnered much attention.

\section{CD8 $\alpha \alpha^{+}$INTESTINAL INTRAEPITHELIAL LYMPHOCYTES (IEL)}

Ly49-expressing $\mathrm{CD}^{+} \mathrm{T}$ cells can be further classified based on whether they express a CD8 $\alpha \alpha$ or $\mathrm{CD} 8 \alpha \beta$ co-receptor. T cells expressing CD8 $\alpha \alpha$ and Ly49 receptors were identified among the IELs (10). Microarray analysis, confirmed by flow cytometry, comparing these cells to traditional intestinal CD8 $\alpha \beta$ T cells showed a marked increase in surface Ly49 expression, with CD8 $\alpha \alpha$ IELs possessing an Ly49 repertoire similar to - but distinct from - the NKT cells discussed above. Notably, although these IELs, like NKT cells, express predominantly inhibitory Ly 49 receptors, the CD8 $\alpha \alpha$ T cells have also been shown to up-regulate Ly49D and H mRNA levels and display an increase in the activating DAP12 adaptor molecule, suggesting they may have some degree of activating Ly49 expression (10). Also, their Ly49 expression profile is remarkable based on its high levels of Ly49E and F, both of which are very rare in NK cell populations. Indeed, the bulk of CD8 $\alpha \alpha$ IELs are Ly49E 
and/or F positive, with the proportion of Ly49E/F double-positive cells roughly corresponding to the product of the proportions of single-positive cells (10). What role these cells may play in gut homeostasis is still unclear, although one report suggests that a subset of Ly49-expressing CD8 $\alpha \alpha$ IELs recognize the non-classical MHC-I molecule Qa-1 (HLA-E in humans) through their TCR and play an immune-regulatory role (117).

\section{CD8 $\alpha \beta^{+}$T CELLS}

In both humans and mice, the CD8 $\alpha \beta$ Ly49-expressing cells are mainly found among the CD122-expressing, memoryphenotype $\mathrm{CD}^{+} \mathrm{T}$ cells: $\mathrm{CD} 25^{-} \mathrm{Ly}^{+} \mathrm{C}^{+} \mathrm{CD} 44^{+}$in mice, and $\mathrm{CD}^{-} 8^{-} \mathrm{CD}_{45 \mathrm{RA}^{-} \mathrm{CD} 45 \mathrm{R}^{+}}{ }^{+}$in humans (118). Despite being memory-phenotype and expanding with the age of the animal, these cells are present from an early age, suggesting that they are not true memory cells but a naturally occurring subpopulation of CD8 ${ }^{+}$T cells (119). As with NKT cells, they appear to express only inhibitory NK receptors. Additionally, like the CD8 $\alpha \alpha$ IELs, these CD8 $\alpha \beta$ T cells have non-NK-like Ly49 repertoires, in this case dominated by Ly49F expression in B6 mice (119).

Attempts to discern the purpose of inhibitory Ly49 or KIR expression on these cells have thus far identified two non-exclusive candidate functions. First, and most intuitive, expression and subsequent engagement of an inhibitory MHC-I receptor downregulates killing activities from the $\mathrm{T}$ cell. Transgenic expression of the inhibitory Ly49A or KIR2DL3 on T cells inhibits their ability to kill MHC-mismatched target cells, provided that those targets express a ligand for the inhibitory NK receptor $(120,121)$. As this role for Ly 49 or KIR expression is shared between T and NK cells, it is probable that it is for the same purpose: both $\mathrm{CD} 8^{+} \mathrm{T}$ cells and NK cells are directly lytic to self-cells while mounting an anti-viral or anti-tumor response, and so must have a method for healthy cells to be recognized and spared to avoid rampant autoimmunity (120). Especially in the case of regulatory T cells (discussed further below), Ly49 expression may allow for a population of $\mathrm{CD}^{+} \mathrm{T}$ cells with highly self-reactive TCRs that are regulated by inhibitory Ly49 receptors, analogous to NK immune surveillance. Such a model also suggests that T cells express only inhibitory Ly49 receptors because their TCR expression is performing a similar role as the activating receptor on the NK cell.

Interestingly, however, these inhibitory NK receptors appear to have a second function on $\mathrm{T}$ cells, conferring enhanced expansion and survival to the Ly49 or KIR positive cell. Although to date there is no study directly showing that Ly49 expression on mouse T cells confers enhanced IL-15 sensitivity, there are lines of evidence to suggest this. First, there is a marked correlation between Ly49 expression and IL-15 sensitivity on mouse $\mathrm{CD}^{+} \mathrm{T}$ cells (122). Using a simple CFSE proliferation assay, this report showed that, although many CD122-expressing T cells are IL-15 sensitive, those that also expressed Ly49 expanded most vigorously after IL-15 stimulation. Second, transgenic expression of a KIR on murine T cells causes those T cells, but not WT or KIR-expressing B cells, to possess a marked proliferation advantage when transferred into mice transgenic for the KIR ligand, but not when transferred into WT mice (118). Taken together, these reports strongly suggest that although Ly49/KIR expression may reduce a T cell's cytotoxicity, it also enhances that cell's longevity.

\section{CD8 ${ }^{+}$T CELLS WITH REGULATORY FUNCTIONS}

Such a paradigm, where Ly $49^{+} \mathrm{T}$ cells are long-lived, broadly active, and/or highly self-reactive cells regulated by inhibitory Ly49 receptors, agrees conceptually with recent work from the Cantor lab and others demonstrating that Ly49-expressing CD8 $\alpha \beta+\mathrm{T}$ cells include or entirely comprise a regulatory population implicated in preventing or controlling such autoimmune diseases as systemic lupus erythematosus (SLE), multiple sclerosis (MS), and rheumatoid arthritis (RA) (123-125). Much like the proposed regulatory $\mathrm{CD} 8 \alpha \alpha \mathrm{T}$ cells above, these $\mathrm{CD} 8 \alpha \beta^{+} \mathrm{T}_{\text {reg }}$ cells are characterized by a TCR restricted to the non-classical MHC molecule Qa-1 (HLA-E in humans) and reacting to a peptide derived from the HSP60 leader sequence (126). They act as indirect regulators of antibody production, by targeting the Qa-1-expressing follicular helper $\mathrm{T}$ cells $\left(\mathrm{T}_{\mathrm{FH}}\right)$ and lysing them in a perforin-dependent manner (127). Employing a strategy not unlike the NK cell use of inhibitory and activating Ly49, these $\mathrm{CD} 8^{+} \mathrm{T}_{\text {reg }}$ cells express NKG2A, an inhibitory NK receptor that recognizes Qa-1 presenting its dominant peptide, Qdm, which normally prevents their killing of $\mathrm{T}_{\mathrm{FH}}$ cells. However, in cases of overactive $\mathrm{T}_{\mathrm{FH}}$ giving rise to excessive antibody production by plasma cells, a shift toward more HSP60sp being presented by Qa-1, allows the CD8 $\mathrm{T}_{\text {reg }}$ cell's TCR to compete with NKG2A and transmit an activating signal to the $\mathrm{CD}^{+} \mathrm{T}_{\text {reg }}$ cell. In a recent report, it was found that disrupting the ability for Qa-1 to interact with the $\mathrm{CD}^{+} \mathrm{T}_{\text {reg }}$ cell's TCR - but not disrupting the NKG2A interaction - caused a massive expansion in $\mathrm{T}_{\mathrm{FH}}$ and plasma cell numbers, splenic germinal center area, and serum and kidney antibody deposition, analogous to that seen in SLE-susceptible mice (127). Furthermore, adoptive transfer of these $\mathrm{CD} 8^{+} \mathrm{T}_{\text {reg }}$ cells into $\mathrm{Rag}^{-1-}$ mice with a reconstituted $\mathrm{CD} 4{ }^{+} \mathrm{CD} 25^{-} \mathrm{T}$ cell and $\mathrm{IgM}^{+} \mathrm{B}$ cell compartment results in a suppression of antibody production upon immunization with NP, which appears to be mediated by the $\mathrm{Ly} 49^{+}$, but not Ly49 $^{-} \mathrm{CD}^{+} \mathrm{T}_{\text {reg }}$ cells (127). While no studies have yet shown a direct role for Ly49 in this regulation, the dual functions discussed above fit well with this model of regulation. On the one hand, the longevity and antigen-independent, IL-15-driven activation and proliferation of these $\mathrm{T}$ cells allows for their continuous presence and immunosurveillance within the organism in question; at the same time, the limiting effect of Ly49 and NKG2A, coupled with the scarcity of this $\mathrm{CD}^{+} \mathrm{T}_{\text {reg }}$ population, ensures that enough antibody is allowed to be produced to protect the host from infection.

\section{CONCLUSION}

Members of the Ly49 family of receptors, like the human KIR, have a broader expression pattern than previously thought. Their expression is not restricted to NK and other cells of the innate immune system, but also found on cells of adaptive immune system. Similarly, their function seems to be broad and vary from regulation of target recognition by NK and possibly NKT cells, regulation of uNK cell functions during pregnancy, sensing of microbial macromolecules and stimulation of cytokine production by $\mathrm{pDC}$, and modulation of autoimmune diseases by affecting survival and function of Ly49-expressing $\mathrm{CD}^{+} \mathrm{T}$ cells. The Ly49:MHC-I interactions are amenable to modulations with potential therapeutic agents, and the recent developments in 
understanding MHC-I receptor expression and function will aid in better design of such strategies.

\section{ACKNOWLEDGMENTS}

Andrew P. Makrigiannis holds a Canada Research Chair in Innate Pathogen Resistance and an Operating Grant from the Canadian Institutes of Health Research (MOP 62841). Megan M. Tu is supported by an Ontario Graduate Scholarship. Andrew Wight is supported by a QEII-GSST scholarship.

\section{REFERENCES}

1. Garboczi DN, Utz U, Ghosh P, Seth A, Kim J, VanTienhoven EA, et al. Assembly, specific binding, and crystallization of a human TCR-alphabeta with an antigenic Tax peptide from human T lymphotropic virus type 1 and the class I MHC molecule HLA-A2. J Immunol (1996) 157(12):5403-10.

2. Garcia KC, Degano M, Stanfield RL, Brunmark A, Jackson MR, Peterson PA, et al. An alphabeta $\mathrm{T}$ cell receptor structure at $2.5 \mathrm{~A}$ and its orientation in the TCR-MHC complex. Science (1996) 274(5285):209-19. doi:10.1126/science. 274.5285.209

3. Hanke T, Takizawa H, McMahon CW, Busch DH, Pamer EG, Miller JD, et al. Direct assessment of MHC class I binding by seven Ly49 inhibitory NK cell receptors. Immunity (1999) 11(1):67-77. doi:10.1016/S1074-7613(00)80082-5

4. Franksson L, Sundback J, Achour A, Bernlind J, Glas R, Karre K. Peptide dependency and selectivity of the NK cell inhibitory receptor Ly-49C. Eur J Immunol (1999) 29(9):2748-58. doi:10.1002/(SICI)1521-4141(199909)29: 09<2748::AID-IMMU2748>3.3.CO;2-3

5. Tormo J, Natarajan K, Margulies DH, Mariuzza RA. Crystal structure of a lectin-like natural killer cell receptor bound to its MHC class I ligand. Nature (1999) 402(6762):623-31. doi:10.1038/45170

6. Toyama-Sorimachi N, Omatsu Y, Onoda A, Tsujimura Y, Iyoda T, Kikuchi-Maki A, et al. Inhibitory NK receptor Ly49Q is expressed on subsets of dendritic cells in a cellular maturation- and cytokine stimulation-dependent manner. J Immunol (2005) 174(8):4621-9.

7. Kamogawa-Schifter Y, Ohkawa J, Namiki S, Arai N, Arai K, Liu Y. Ly49Q defines 2 pDC subsets in mice. Blood (2005) 105(7):2787-92. doi:10.1182/blood-200409-3388

8. Gays F, Aust JG, Reid DM, Falconer J, Toyama-Sorimachi N, Taylor PR, et al. Ly49B is expressed on multiple subpopulations of myeloid cells. J Immunol (2006) 177(9):5840-51.

9. Ortaldo JR, Winkler-Pickett R, Mason AT, Mason LH. The Ly-49 family: regulation of cytotoxicity and cytokine production in murine CD3+ cells. J Immunol (1998) 160(3):1158-65.

10. Denning TL, Granger SW, Mucida D, Graddy R, Leclercq G, Zhang W, et al. Mouse TCR alphabeta+CD8alphaalpha intraepithelial lymphocytes express genes that down-regulate their antigen reactivity and suppress immune responses. J Immunol (2007) 178(7):4230-9.

11. Yadi H, Burke S, Madeja Z, Hemberger M, Moffett A, Colucci F. Unique receptor repertoire in mouse uterine NK cells. J Immunol (2008) 181(9):6140-7.

12. Maeda M, Lohwasser S, Yamamura T, Takei F. Regulation of NKT cells by Ly49: analysis of primary NKT cells and generation of NKT cell line. J Immunol (2001) 167(8):4180-6.

13. Kim S, Poursine-Laurent J, Truscott SM, Lybarger L, Song YJ, Yang L, et al. Licensing of natural killer cells by host major histocompatibility complex class I molecules. Nature (2005) 436(7051):709-13. doi:10.1038/nature03847

14. Olcese L, Lang P, Vely F, Cambiaggi A, Marguet D, Blery M, et al. Human and mouse killer-cell inhibitory receptors recruit PTP1C and PTP1D protein tyrosine phosphatases. J Immunol (1996) 156(12):4531-4.

15. Vivier E, Daeron M. Immunoreceptor tyrosine-based inhibition motifs. Immunol Today (1997) 18(6):286-91. doi:10.1016/S0167-5699(97)80025-4

16. Vely F, Vivier E. Conservation of structural features reveals the existence of a large family of inhibitory cell surface receptors and noninhibitory/activatory counterparts. J Immunol (1997) 159(5):2075-7.

17. Mason LH, Gosselin P, Anderson SK, Fogler WE, Ortaldo JR, McVicar DW. Differential tyrosine phosphorylation of inhibitory versus activating Ly-49 receptor proteins and their recruitment of SHP-1 phosphatase. J Immunol (1997) 159(9):4187-96.
18. D’Ambrosio D, Hippen KL, Minskoff SA, Mellman I, Pani G, Siminovitch KA, et al. Recruitment and activation of PTP1C in negative regulation of antigen receptor signaling by Fc gamma RIIB1. Science (1995) 268(5208):293-7. doi:10.1126/science.7716523

19. Nakamura MC, Niemi EC, Fisher MJ, Shultz LD, Seaman WE, Ryan JC. Mouse Ly-49A interrupts early signaling events in natural killer cell cytotoxicity and functionally associates with the SHP-1 tyrosine phosphatase. J Exp Med (1997) 185(4):673-84. doi:10.1084/jem.185.4.673

20. Blery M, Delon J, Trautmann A, Cambiaggi A, Olcese L, Biassoni R, et al. Reconstituted killer cell inhibitory receptors for major histocompatibility complex class I molecules control mast cell activation induced via immunoreceptor tyrosine-based activation motifs. J Biol Chem (1997) 272(14):8989-96. doi:10.1074/jbc.272.14.8989

21. Binstadt BA, Brumbaugh KM, Dick CJ, Scharenberg AM, Williams BL, Colonna $\mathrm{M}$, et al. Sequential involvement of Lck and SHP-1 with MHC-recognizing receptors on NK cells inhibits FcR-initiated tyrosine kinase activation. Immunity (1996) 5(6):629-38. doi:10.1016/S1074-7613(00)80276-9

22. Smith KM, Wu J, Bakker AB, Phillips JH, Lanier LL. Ly-49D and Ly-49H associate with mouse DAP12 and form activating receptors. J Immunol (1998) 161(1):7-10.

23. Gosselin P, Mason LH, Willette-Brown J, Ortaldo JR, McVicar DW, Anderson SK. Induction of DAP12 phosphorylation, calcium mobilization, and cytokine secretion by Ly49H. J Leukoc Biol (1999) 66(1):165-71.

24. Makrigiannis AP, Gosselin P, Mason LH, Taylor LS, McVicar DW, Ortaldo JR, et al. Cloning and characterization of a novel activating Ly49 closely related to Ly49A. J Immunol (1999) 163(9):4931-8.

25. Mason LH, Willette-Brown J, Anderson SK, Gosselin P, Shores EW, Love $\mathrm{PE}$, et al. Characterization of an associated $16-\mathrm{kDa}$ tyrosine phosphoprotein required for Ly-49D signal transduction. J Immunol (1998) 160(9):4148-52.

26. McVicar DW, Taylor LS, Gosselin P, Willette-Brown J, Mikhael AI, Geahlen RL, et al. DAP12-mediated signal transduction in natural killer cells. A dominant role for the Syk protein-tyrosine kinase. J Biol Chem (1998) 273(49):32934-42. doi:10.1074/jbc.273.49.32934

27. Yokoyama WM, Kehn PJ, Cohen DI, Shevach EM. Chromosomal location of the Ly-49 (A1, YE1/48) multigene family. Genetic association with the NK 1.1 antigen. J Immunol (1990) 145(7):2353-8.

28. Makrigiannis AP, Pau AT, Schwartzberg PL, McVicar DW, Beck TW, Anderson SK. A BAC contig map of the Ly49 gene cluster in 129 mice reveals extensive differences in gene content relative to C57BL/6 mice. Genomics (2002) 79(3):437-44. doi:10.1006/geno.2002.6724

29. Makrigiannis AP, Patel D, Goulet ML, Dewar K, Anderson SK. Direct sequence comparison of two divergent class I MHC natural killer cell receptor haplotypes. Genes Immun (2005) 6(2):71-83. doi:10.1038/sj.gene.6364154

30. Proteau MF, Rousselle E, Makrigiannis AP. Mapping of the BALB/c Ly49 cluster defines a minimal natural killer cell receptor gene repertoire. Genomics (2004) 84(4):669-77. doi:10.1016/j.ygeno.2004.05.004

31. Ortaldo JR, Mason AT, Winkler-Pickett R, Raziuddin A, Murphy WJ, Mason LH. Ly-49 receptor expression and functional analysis in multiple mouse strains. J Leukoc Biol (1999) 66(3):512-20.

32. Anderson SK, Dewar K, Goulet ML, Leveque G, Makrigiannis AP. Complete elucidation of a minimal class I MHC natural killer cell receptor haplotype. Genes Immun (2005) 6(6):481-92. doi:10.1038/sj.gene.6364232

33. Belanger S, Tai LH, Anderson SK, Makrigiannis AP. Ly49 cluster sequence analysis in a mouse model of diabetes: an expanded repertoire of activating receptors in the NOD genome. Genes Immun (2008) 9(6):509-21. doi:10.1038/gene.2008.43

34. Brown MG, Fulmek S, Matsumoto K, Cho R, Lyons PA, Levy ER, et al. A 2-Mb YAC contig and physical map of the natural killer gene complex on mouse chromosome 6. Genomics (1997) 42(1):16-25. doi:10.1006/geno.1997.4721

35. McQueen KL, Freeman JD, Takei F, Mager DL. Localization of five new Ly49 genes, including three closely related to Ly49c. Immunogenetics (1998) 48(3):174-83. doi:10.1007/s002510050421

36. Depatie C, Lee SH, Stafford A, Avner P, Belouchi A, Gros P, et al. Sequenceready $\mathrm{BAC}$ contig, physical, and transcriptional map of a 2-Mb region overlapping the mouse chromosome 6 host-resistance locus Cmv1. Genomics (2000) 66(2):161-74. doi:10.1006/geno.2000.6186

37. Makrigiannis AP, Anderson SK. The murine Ly49 family: form and function. Arch Immunol Ther Exp (Warsz) (2001) 49(1):47-50. 
38. McQueen KL, Lohwasser S, Takei F, Mager DL. Expression analysis of new Ly49 genes: most transcripts of Ly49j lack the transmembrane domain. Immunogenetics (1999) 49(7-8):685-91. doi:10.1007/s002510050665

39. Silver ET, Gong D, Hazes B, Kane KP. Ly-49W, an activating receptor of nonobese diabetic mice with close homology to the inhibitory receptor Ly-49G, recognizes $\mathrm{H}-2 \mathrm{D}(\mathrm{k})$ and $\mathrm{H}-2 \mathrm{D}(\mathrm{d})$. J Immunol (2001) 166(4):2333-41.

40. Biron CA, Byron KS, Sullivan JL. Severe herpesvirus infections in an adolescent without natural killer cells. $N$ Engl J Med (1989) 320(26):1731-5. doi:10.1056/NEJM198906293202605

41. Orange JS. Human natural killer cell deficiencies and susceptibility to infection. Microbes Infect (2002) 4(15):1545-58. doi:10.1016/S1286-4579(02)00038-2

42. Scalzo AA, Fitzgerald NA, Simmons A, La Vista AB, Shellam GR. Cmv-1, a genetic locus that controls murine cytomegalovirus replication in the spleen. J Exp Med (1990) 171(5):1469-83. doi:10.1084/jem.171.5.1469

43. Lee SH, Girard S, Macina D, Busa M, Zafer A, Belouchi A, et al. Susceptibility to mouse cytomegalovirus is associated with deletion of an activating natural killer cell receptor of the C-type lectin superfamily. Nat Genet (2001) 28(1):42-5. doi:10.1038/88247

44. Brown MG, Dokun AO, Heusel JW, Smith HR, Beckman DL, Blattenberger EA, et al. Vital involvement of a natural killer cell activation receptor in resistance to viral infection. Science (2001) 292(5518):934-7. doi:10.1126/science.1060042

45. Daniels KA, Devora G, Lai WC, O’Donnell CL, Bennett M, Welsh RM. Murine cytomegalovirus is regulated by a discrete subset of natural killer cells reactive with monoclonal antibody to Ly49H. J Exp Med (2001) 194(1):29-44. doi:10.1084/jem.194.1.29

46. Arase H, Mocarski ES, Campbell AE, Hill AB, Lanier LL. Direct recognition of cytomegalovirus by activating and inhibitory NK cell receptors. Science (2002) 296(5571):1323-6. doi:10.1126/science.1070884

47. Smith HR, Heusel JW, Mehta IK, Kim S, Dorner BG, Naidenko OV, et al. Recognition of a virus-encoded ligand by a natural killer cell activation receptor. Proc Natl Acad Sci U S A (2002) 99(13):8826-31. doi:10.1073/pnas.092258599

48. Kubota A, Kubota S, Lohwasser S, Mager DL, Takei F. Diversity of NK cell receptor repertoire in adult and neonatal mice. J Immunol (1999) 163(1):212-6.

49. Kim S, Iizuka K, Kang HS, Dokun A, French AR, Greco S, et al. In vivo developmental stages in murine natural killer cell maturation. Nat Immunol (2002) 3(6):523-8. doi:10.1038/ni796

50. Van BK, Stevenaert F, De CA, Debacker V, De BJ, Plum J, et al. Expression of Ly49E and CD94/NKG2 on fetal and adult NK cells. J Immunol (2001) 166(7):4302-11.

51. Dorfman JR, Raulet DH. Acquisition of Ly49 receptor expression by developing natural killer cells. J Exp Med (1998) 187(4):609-18. doi:10.1084/jem.187.4.609

52. Karre K, Ljunggren HG, Piontek G, Kiessling R. Selective rejection of H-2deficient lymphoma variants suggests alternative immune defence strategy. Nature (1986) 319(6055):675-8. doi:10.1038/319675a0

53. Liao NS, Bix M, Zijlstra M, Jaenisch R, Raulet D. MHC class I deficiency: susceptibility to natural killer (NK) cells and impaired NK activity. Science (1991) 253(5016):199-202. doi:10.1126/science. 1853205

54. Belanger S, Tu MM, Rahim MM, Mahmoud AB, Patel R, Tai LH, et al. Impaired natural killer cell self-education and "missing-self" responses in Ly49-deficient mice. Blood (2012) 120(3):592-602. doi:10.1182/blood-2012-02-408732

55. Kim S, Sunwoo JB, Yang L, Choi T, Song YJ, French AR, et al. HLA alleles determine differences in human natural killer cell responsiveness and potency. Proc Natl Acad Sci U S A (2008) 105(8):3053-8. doi:10.1073/pnas.0712229105

56. Anfossi N, Andre P, Guia S, Falk CS, Roetynck S, Stewart CA, et al. Human NK cell education by inhibitory receptors for MHC class I. Immunity (2006) 25(2):331-42. doi:10.1016/j.immuni.2006.06.013

57. Elliott JM, Wahle JA, Yokoyama WM. MHC class I-deficient natural killer cells acquire a licensed phenotype after transfer into an MHC class I-sufficient environment. J Exp Med (2010) 207(10):2073-9. doi:10.1084/jem.20100986

58. Joncker NT, Shifrin N, Delebecque F, Raulet DH. Mature natural killer cells reset their responsiveness when exposed to an altered MHC environment. J Exp Med (2010) 207(10):2065-72. doi:10.1084/jem.20100570

59. Raulet DH, Vance RE. Self-tolerance of natural killer cells. Nat Rev Immunol (2006) 6(7):520-31. doi:10.1038/nri1863

60. Ebihara T, Jonsson AH, Yokoyama WM. Natural killer cell licensing in mice with inducible expression of MHC class I. Proc Natl Acad Sci U S A (2013) 110(45):E4232-7. doi:10.1073/pnas.1318255110
61. Chalifour A, Scarpellino L, Back J, Brodin P, Devevre E, Gros F, et al. A role for cis interaction between the inhibitory Ly49A receptor and MHC class I for natural killer cell education. Immunity (2009) 30(3):337-47. doi:10.1016/j.immuni.2008.12.019

62. Bessoles S, Angelov GS, Back J, Leclercq G, Vivier E, Held W. Education of murine NK cells requires both cis and trans recognition of MHC class I molecules. J Immunol (2013) 191(10):5044-51. doi:10.4049/jimmunol.1301971

63. Garcia-Lora A, Algarra I, Collado A, Garrido F. Tumour immunology, vaccination and escape strategies. Eur J Immunogenet (2003) 30(3):177-83. doi:10.1046/j.1365-2370.2003.00384.x

64. Maleno I, Lopez-Nevot MA, Cabrera T, Salinero J, Garrido F. Multiple mechanisms generate HLA class I altered phenotypes in laryngeal carcinomas: high frequency of HLA haplotype loss associated with loss of heterozygosity in chromosome region 6p21. Cancer Immunol Immunother (2002) 51(7):389-96. doi:10.1007/s00262-002-0296-0

65. Drenou B, Tilanus M, Semana G, Alizadeh M, Birebent B, Grosset JM, et al. Loss of heterozygosity, a frequent but a non-exclusive mechanism responsible for HLA dysregulation in non-Hodgkin's lymphomas. Br J Haematol (2004) 127(1):40-9. doi:10.1111/j.1365-2141.2004.05151.x

66. Ryschich E, Cebotari O, Fabian OV, Autschbach F, Kleeff J, Friess H, et al. Loss of heterozygosity in the HLA class I region in human pancreatic cancer. Tissue Antigens (2004) 64(6):696-702. doi:10.1111/j.1399-0039.2004.00324.x

67. Koh CY, Blazar BR, George T, Welniak LA, Capitini CM, Raziuddin A, et al. Augmentation of antitumor effects by NK cell inhibitory receptor blockade in vitro and in vivo. Blood (2001) 97(10):3132-7. doi:10.1182/blood.V97.10.3132

68. Romagne F, Andre P, Spee P, Zahn S, Anfossi N, Gauthier L, et al. Preclinical characterization of 1-7F9, a novel human anti-KIR receptor therapeutic antibody that augments natural killer-mediated killing of tumor cells. Blood (2009) 114(13):2667-77. doi:10.1182/blood-2009-02-206532

69. Vey N, Bourhis JH, Boissel N, Bordessoule D, Prebet T, Charbonnier A, et al. A phase 1 trial of the anti-inhibitory KIR mAb IPH2101 for AML in complete remission. Blood (2012) 120(22):4317-23. doi:10.1182/blood-2012-06437558

70. Benson DM Jr, Hofmeister CC, Padmanabhan S, Suvannasankha A, Jagannath $\mathrm{S}$, Abonour R, et al. A phase 1 trial of the anti-KIR antibody IPH2101 in patients with relapsed/refractory multiple myeloma. Blood (2012) 120(22):4324-33. doi:10.1182/blood-2012-06-438028

71. Andrews DM, Sullivan LC, Baschuk N, Chan CJ, Berry R, Cotterell CL, et al. Recognition of the nonclassical MHC class I molecule H2-M3 by the receptor Ly49A regulates the licensing and activation of NK cells. Nat Immunol (2012) 13(12):1171-7. doi:10.1038/ni.2468

72. Xu H, Chun T, Choi HJ, Wang B, Wang CR. Impaired response to Listeria in H2-M3-deficient mice reveals a nonredundant role of MHC class Ib-specific T cells in host defense. J Exp Med (2006) 203(2):449-59. doi:10.1084/jem. 20051866

73. Tarek N, Le Luduec JB, Gallagher MM, Zheng J, Venstrom JM, Chamberlain E, et al. Unlicensed NK cells target neuroblastoma following anti-GD2 antibody treatment. J Clin Invest (2012) 122(9):3260-70. doi:10.1172/JCI62749

74. Rajagopalan S, Long EO. Viral evasion of NK-cell activation. Trends Immunol (2005) 26(8):403-5. doi:10.1016/j.it.2005.06.008

75. Bubic I, Wagner M, Krmpotic A, Saulig T, Kim S, Yokoyama WM, et al. Gain of virulence caused by loss of a gene in murine cytomegalovirus. J Virol (2004) 78(14):7536-44. doi:10.1128/JVI.78.14.7536-7544.2004

76. Xie X, Dighe A, Clark P, Sabastian P, Buss S, Brown MG. Deficient major histocompatibility complex-linked innate murine cytomegalovirus immunity in MA/My.L-H2b mice and viral downregulation of H-2k class I proteins. J Virol (2007) 81(1):229-36. doi:10.1128/JVI.00997-06

77. Kielczewska A, Pyzik M, Sun T, Krmpotic A, Lodoen MB, Munks MW, et al. Ly49P recognition of cytomegalovirus-infected cells expressing H2-Dk and CMV-encoded m04 correlates with the NK cell antiviral response. J Exp Med (2009) 206(3):515-23. doi:10.1084/jem.20080954

78. Orr MT, Murphy WJ, Lanier LL. 'Unlicensed' natural killer cells dominate the response to cytomegalovirus infection. Nat Immunol (2010) 11(4):321-7. doi:10.1038/ni.1849

79. Mallidi TV, Craig LE, Schloemann SR, Riley JK. Murine endometrial and decidual NK1.1+ natural killer cells display a B220+CD11c+ cell surface phenotype. Biol Reprod (2009) 81(2):310-8. doi:10.1095/biolreprod.109.076448 
80. Kiso Y, McBey BA, Mason L, Croy BA. Histological assessment of the mouse uterus from birth to puberty for the appearance of LGL-1+ natural killer cells. Biol Reprod (1992) 47(2):227-32. doi:10.1095/biolreprod47.2.227

81. Croy BA, Esadeg S, Chantakru S, van den Heuvel M, Paffaro VA, He H, et al. Update on pathways regulating the activation of uterine natural killer cells, their interactions with decidual spiral arteries and homing of their precursors to the uterus. J Reprod Immunol (2003) 59(2):175-91. doi:10.1016/S01650378(03)00046-9

82. Peel S. Granulated metrial gland cells. Adv Anat Embryol Cell Biol (1989) 115:1-112.

83. Paffaro VA Jr, Bizinotto MC, Joazeiro PP, Yamada AT. Subset classification of mouse uterine natural killer cells by DBA lectin reactivity. Placenta (2003) 24(5):479-88. doi:10.1053/plac.2002.0919

84. Chiossone L, Vacca P, Orecchia P, Croxatto D, Damonte P, Astigiano S, et al. In vivo generation of decidual natural killer cells from resident hematopoietic progenitors. Haematologica (2014) 99(3):448-57. doi:10.3324/haematol.2013. 091421

85. Chen Z, Zhang J, Hatta K, Lima PD, Yadi H, Colucci F, et al. DBA-lectin reactivity defines mouse uterine natural killer cell subsets with biased gene expression. Biol Reprod (2012) 87(4):81. doi:10.1095/biolreprod.112.102293

86. Lima PD, Croy BA, Degaki KY, Tayade C, Yamada AT. Heterogeneity in composition of mouse uterine natural killer cell granules. J Leukoc Biol (2012) 92(1):195-204. doi:10.1189/jlb.0312136

87. Ashkar AA, Di Santo JP, Croy BA. Interferon gamma contributes to initiation of uterine vascular modification, decidual integrity, and uterine natural killer cell maturation during normal murine pregnancy. J Exp Med (2000) 192(2):259-70. doi:10.1084/jem.192.2.259

88. Tayade C, Hilchie D, He H, Fang Y, Moons L, Carmeliet P, et al. Genetic deletion of placenta growth factor in mice alters uterine NK cells. J Immunol (2007) 178(7):4267-75.

89. Degaki KY, Chen Z, Yamada AT, Croy BA. Delta-like ligand (DLL)1 expression in early mouse decidua and its localization to uterine natural killer cells. PLoS One (2012) 7(12):e52037. doi:10.1371/journal.pone.0052037

90. Hofmann AP, Gerber SA, Croy BA. Uterine natural killer cells pace early development of mouse decidua basalis. Mol Hum Reprod (2014) 20(1):66-76. doi:10.1093/molehr/gat060

91. Chantakru S, Miller C, Roach LE, Kuziel WA, Maeda N, Wang WC, et al. Contributions from self-renewal and trafficking to the uterine NK cell population of early pregnancy. J Immunol (2002) 168(1):22-8.

92. Madeja Z, Yadi H, Apps R, Boulenouar S, Roper SJ, Gardner L, et al. Paternal MHC expression on mouse trophoblast affects uterine vascularization and fetal growth. Proc Natl Acad Sci U S A (2011) 108(10):4012-7. doi:10.1073/ pnas. 1005342108

93. Makrigiannis AP, Pau AT, Saleh A, Winkler-Pickett R, Ortaldo JR, Anderson SK. Class I MHC-binding characteristics of the 129/J Ly49 repertoire. J Immunol (2001) 166(8):5034-43.

94. Johansson S, Salmon-Divon M, Johansson MH, Pickman Y, Brodin P, Karre K, et al. Probing natural killer cell education by Ly49 receptor expression analysis and computational modelling in single MHC class I mice. PLoS One (2009) 4(6):e6046. doi:10.1371/journal.pone.0006046

95. Cannon MJ. Congenital cytomegalovirus (CMV) epidemiology and awareness. J Clin Virol (2009) 46(Suppl 4):S6-10. doi:10.1016/j.jcv.2009.09.002

96. Siewiera J, El CH, Tabiasco J, Berrebi A, Cartron G, Le BP, et al. Human cytomegalovirus infection elicits new decidual natural killer cell effector functions. PLoS Pathog (2013) 9(4):e1003257. doi:10.1371/journal.ppat. 1003257

97. Gombos RB, Wolan V, McDonald K, Hemmings DG. Impaired vascular function in mice with an active cytomegalovirus infection. Am J Physiol Heart Circ Physiol (2009) 296(4):H937-45. doi:10.1152/ajpheart.01027.2008

98. Hatta K, Carter AL, Chen Z, Leno-Duran E, Ruiz-Ruiz C, Olivares EG, et al. Expression of the vasoactive proteins AT1, AT2, and ANP by pregnancyinduced mouse uterine natural killer cells. Reprod Sci (2011) 18(4):383-90. doi:10.1177/1933719110385136

99. Borg NA, Wun KS, Kjer-Nielsen L, Wilce MC, Pellicci DG, Koh R, et al. CD1dlipid-antigen recognition by the semi-invariant NKT T-cell receptor. Nature (2007) 448(7149):44-9. doi:10.1038/nature05907

100. Pellicci DG, Patel O, Kjer-Nielsen L, Pang SS, Sullivan LC, Kyparissoudis K, et al. Differential recognition of CD1d-alpha-galactosyl ceramide by the $\mathrm{V}$ beta 8.2 and V beta 7 semi-invariant NKT T cell receptors. Immunity (2009) 31(1):47-59. doi:10.1016/j.immuni.2009.04.018

101. Skold M, Stenstrom M, Sidobre S, Hoglund P, Kronenberg M, Cardell S. MHCdependent and -independent modulation of endogenous Ly49 receptors on NK1.1 + T lymphocytes directed by T-cell receptor type. Immunology (2003) 110(3):313-21. doi:10.1046/j.1365-2567.2003.01741.x

102. Merck E, Lees RK, Voyle RB, Held W, MacDonald HR. Ly49D-mediated ITAM signaling in immature thymocytes impairs development by bypassing the pre-TCR checkpoint. J Immunol (2011) 187(1):110-7. doi:10.4049/jimmunol. 1002755

103. Matsuda JL, Naidenko OV, Gapin L, Nakayama T, Taniguchi M, Wang CR, et al. Tracking the response of natural killer $\mathrm{T}$ cells to a glycolipid antigen using CD1d tetramers. J Exp Med (2000) 192(5):741-54. doi:10.1084/jem.192.5.741

104. Yokoyama WM. Natural killer cell receptors specific for major histocompatibility complex class I molecules. Proc Natl Acad Sci U S A (1995) 92(8):3081-5. doi:10.1073/pnas.92.8.3081

105. Zeng D, Gazit G, Dejbakhsh-Jones S, Balk SP, Snapper S, Taniguchi M, et al. Heterogeneity of NK1.1 $\mathrm{T}$ cells in the bone marrow: divergence from the thymus. J Immunol (1999) 163(10):5338-45.

106. Makino Y, Yamagata N, Sasho T, AdachiY, Kanno R, Koseki H, et al. Extrathymic development of V alpha 14-positive T cells. J Exp Med (1993) 177(5):1399-408. doi:10.1084/jem.177.5.1399

107. Toyama-Sorimachi N, Tsujimura Y, Maruya M, Onoda A, Kubota T, Koyasu S, et al. Ly49Q, a member of the Ly49 family that is selectively expressed on myeloid lineage cells and involved in regulation of cytoskeletal architecture. Proc Natl Acad Sci U S A (2004) 101(4):1016-21. doi:10.1073/pnas.0305400101

108. Sasawatari S, Yoshizaki M, Taya C, Tazawa A, Furuyama-Tanaka K, Yonekawa $\mathrm{H}$, et al. The Ly49Q receptor plays a crucial role in neutrophil polarization and migration by regulating raft trafficking. Immunity (2010) 32(2):200-13. doi:10.1016/j.immuni.2010.01.012

109. Hayashi M, Nakashima T, Kodama T, Makrigiannis AP, Toyama-Sorimachi N, Takayanagi H. Ly49Q, an ITIM-bearing NK receptor, positively regulates osteoclast differentiation. Biochem Biophys Res Commun (2010) 393(3):432-8. doi:10.1016/j.bbrc.2010.02.013

110. Omatsu Y, Iyoda T, Kimura Y, Maki A, Ishimori M, Toyama-Sorimachi $\mathrm{N}$, et al. Development of murine plasmacytoid dendritic cells defined by increased expression of an inhibitory NK receptor, Ly49Q. J Immunol (2005) 174(11):6657-62.

111. Siegal FP, Kadowaki N, Shodell M, Fitzgerald-Bocarsly PA, Shah K, Ho S, et al. The nature of the principal type 1 interferon-producing cells in human blood. Science (1999) 284(5421):1835-7. doi:10.1126/science.284.5421.1835

112. Zucchini N, Bessou G, Traub S, Robbins SH, Uematsu S, Akira S, et al. Cutting edge: overlapping functions of TLR7 and TLR9 for innate defense against a herpesvirus infection. J Immunol (2008) 180(9):5799-803.

113. Tai LH, Goulet ML, Belanger S, Toyama-Sorimachi N, Fodil-Cornu N, Vidal $\mathrm{SM}$, et al. Positive regulation of plasmacytoid dendritic cell function via Ly49Q recognition of class I MHC. J Exp Med (2008) 205(13):3187-99. doi:10.1084/jem.20080718

114. Rahim MM, Tai LH, Troke AD, Mahmoud AB, Abou-Samra E, Roy JG, et al. Ly49Q positively regulates type I IFN production by plasmacytoid dendritic cells in an immunoreceptor tyrosine-based inhibitory motif-dependent manner. J Immunol (2013) 190(8):3994-4004. doi:10.4049/jimmunol.1200873

115. Sivori S, Falco M, Carlomagno S, Romeo E, Soldani C, Bensussan A, et al. A novel KIR-associated function: evidence that CpG DNA uptake and shuttling to early endosomes is mediated by KIR3DL2. Blood (2010) 116(10):1637-47. doi:10.1182/blood-2009-12-256586

116. Yoshizaki M, Tazawa A, Kasumi E, Sasawatari S, Itoh K, Dohi T, et al. Spatiotemporal regulation of intracellular trafficking of Toll-like receptor 9 by an inhibitory receptor, Ly49Q. Blood (2009) 114(8):1518-27. doi:10.1182/blood2008-12-192344

117. Fanchiang SS, Cojocaru R, Othman M, Khanna R, Brooks MJ, Smith T, et al. Global expression profiling of peripheral Qa-1-restricted CD8alphaalpha+TCR alphabeta+ regulatory $\mathrm{T}$ cells reveals innate-like features: implications for immune-regulatory repertoire. Hum Immunol (2012) 73(3):214-22. doi:10.1016/j.humimm.2011.07.306

118. Ugolini S, Arpin C, Anfossi N, Walzer T, Cambiaggi A, Forster R, et al. Involvement of inhibitory NKRs in the survival of a subset of memory-phenotype CD8+ T cells. Nat Immunol (2001) 2(5):430-5. doi:10.1038/85246 
119. Coles MC, Raulet DH. NK1.1+ T cells in the liver arise in the thymus and are selected by interactions with class I molecules on CD4+CD8+ cells. J Immunol (2000) 164(5):2412-8.

120. Zajac AJ, Vance RE, Held W, Sourdive DJ, Altman JD, Raulet DH, et al. Impaired anti-viral T cell responses due to expression of the Ly49A inhibitory receptor. J Immunol (1999) 163(10):5526-34.

121. Cambiaggi A, Verthuy C, Naquet P, Romagne F, Ferrier P, Biassoni $\mathrm{R}$, et al. Natural killer cell acceptance of $\mathrm{H}-2$ mismatch bone marrow grafts in transgenic mice expressing HLA-Cw3 specific killer cell inhibitory receptor. Proc Natl Acad Sci U S A (1997) 94(15):8088-92. doi:10.1073/pnas. 94.15.8088

122. Judge AD, Zhang X, Fujii H, Surh CD, Sprent J. Interleukin 15 controls both proliferation and survival of a subset of memory-phenotype CD8(+) T cells. J Exp Med (2002) 196(7):935-46. doi:10.1084/jem.20020772

123. Kim HJ, Wang X, Radfar S, Sproule TJ, Roopenian DC, Cantor H. CD8+ T regulatory cells express the Ly49 Class I MHC receptor and are defective in autoimmune prone B6-Yaa mice. Proc Natl Acad Sci U S A (2011) 108(5):2010-5. doi:10.1073/pnas.1018974108

124. Hu D, Ikizawa K, Lu L, Sanchirico ME, Shinohara ML, Cantor H. Analysis of regulatory CD8 T cells in Qa-1-deficient mice. Nat Immunol (2004) 5(5):516-23. doi:10.1038/ni1063

125. Leavenworth JW, Tang X, Kim HJ, Wang X, Cantor H. Amelioration of arthritis through mobilization of peptide-specific CD8+ regulatory T cells. J Clin Invest (2013) 123(3):1382-9. doi:10.1172/JCI66938
126. Jiang H, Ware R, Stall A, Flaherty L, Chess L, Pernis B. Murine CD8+ T cells that specifically delete autologous CD4+ T cells expressing V beta 8 TCR: a role of the Qa-1 molecule. Immunity (1995) 2(2):185-94. doi:10.1016/S10747613(95)80079-4

127. Kim HJ, Verbinnen B, Tang X, Lu L, Cantor H. Inhibition of follicular T-helper cells by CD8(+) regulatory T cells is essential for self tolerance. Nature (2010) 467(7313):328-32. doi:10.1038/nature09370

Conflict of Interest Statement: The authors declare that the research was conducted in the absence of any commercial or financial relationships that could be construed as a potential conflict of interest.

Received: 13 January 2014; accepted: 20 March 2014; published online: 02 April 2014. Citation: Rahim MMA, Tu MM, Mahmoud AB, Wight A, Abou-Samra E, Lima PDA and Makrigiannis AP (2014) Ly49 receptors: innate and adaptive immune paradigms. Front. Immunol. 5:145. doi: 10.3389/fimmu.2014.00145

This article was submitted to Molecular Innate Immunity, a section of the journal Frontiers in Immunology.

Copyright (c) 2014 Rahim, Tu, Mahmoud, Wight, Abou-Samra, Lima and Makrigiannis. This is an open-access article distributed under the terms of the Creative Commons Attribution License (CC BY). The use, distribution or reproduction in other forums is permitted, provided the original author(s) or licensor are credited and that the original publication in this journal is cited, in accordance with accepted academic practice. No use, distribution or reproduction is permitted which does not comply with these terms. 